\title{
PENINGKATAN BERPIKIR INTUISI DAN PENALARAN MATEMATIS MELALUI PEMBELAJARAN INQUIRY BERBASIS OPEN-ENDED
}

\author{
${ }^{1}$ Yatha Yuni, ${ }^{2}$ Darhim, ${ }^{3}$ Turmudi \\ ${ }^{1}$ STKIP Kusuma Negara Jakarta \\ ${ }^{2}$ Universitas Pendidikan Indonesia (UPI) \\ ${ }^{3}$ Universitas Pendidikan Indonesia (UPI) \\ e-mail: yathayuni@stkipkusumanegara.ac.id
}

\begin{abstract}
Abstrak
Penelitian ini bertujuan menganalisis peningkatan kemampuan berpikir intuisi, dan penalaran matematis peserta didik yang mendapat pembelajaran Inquiry Berbasis Open-ended dan pembelajaran biasa. Peningkatan ditinjau secara keseluruhan dan berdasarkan kemampuan awal matematis (KAM tinggi, sedang, dan rendah). Metode penelitian menggunakan rancangan non-equivalent pre-test and post-test control-group design. Subjek penelitian melibatkan 156 peserta didik kelas 7 Madrasah Tsanawiyah di Bekasi, terdiri dari dua kelas eksperimen dan dua kelas kontrol dipilih secara purposive. Instrumen penelitian menggunakan soal bentuk uraian untuk mengukur kemampuan intuisi dan penalaran matematis. Hasil penelitian menunjukkan bahwa: (1) Secara keseluruhan dan KAM, peningkatan kemampuan berpikir intuisi matematis peserta didik yang mendapat pembelajaran Inquiry Berbasis Open-ended lebih baik dari pembelajaran biasa. (2) Peningkatan kemampuan penalaran matematis pada KAM tinggi dan rendah, lebih baik pada kelas pembelajaran Inquiry Berbasis Open-ended dibandingkan kelas pembelajaran biasa. Namun secara keseluruhan dan KAM sedang, kelas pembelajaran Inquiry Berbasis Openended tidak lebih baik dibandingkan kelas pembelajaran biasa.
\end{abstract}

Kata Kunci: Intuisi, Penalaran, Inquiry Berbasis Open-ended.

\begin{abstract}
This research aims to examine the improvement of students' abilities in mathematical intuition and mathematical reasoning through Open-ended based inquiry learning and general learning. The students' improvement studied based generally and based on pre-mathematical ability. The research method used non-equivalent pre-test and post-test control-group design. The sample included 156 seventh grade students of two Islamic secondary schools in Bekasi. Based on students' pre-mathematical ability, the groups were classified into high, moderate, and low. The results of this research are: (1) Generally, there are improvement in mathematical intuitive thinking ability after Open-ended based inquiry learning applied for high, moderate and low pre-mathematical ability; (2) Generally, by moderate pre-mathemathical ability, the students' improvement in mathematical reasoning ability through Open-ended based inquiry learning is not better than general learning, meanwhile there is an improvement in mathematical reasoning ability for students with high and low pre-mathemathical ability through Open-ended based inquiry learning.
\end{abstract}

Keywords: Intuition, Reasoning, Open-ended based Inquiry Learning.

\section{PENDAHULUAN}

Banyak jenis pelajaran yang diajarkan di sekolah formal, diantaranya adalah matematika. Tujuan pembelajaran matematika diajarkan di sekolah, salah satunya untuk mengasah peserta didik agar memiliki kemampuan dasar dalam proses belajar matematika. Kemampuan dasar yang dimaksud sesuai dengan standar matematika sekolah yang dikemukakan oleh National Council of Teachers of Mathematics (NCTM, 2000) meliputi: (1) Problem Solving, belajar untuk memecahkan masalah matematika; (2) Reasoning and Proof, belajar untuk bernalar dan 
membuktikan; (3) Communication, belajar untuk berbagi ide dan mengklarifikasi pemahaman matematik; (4) Connection, belajar untuk mengaitkan ide; (5) Representation, belajar mengungkapkan gagasan matematis dalam berbagai cara, diantaranya dengan membuat gambar, grafik, tabel, simbol, angka \& huruf, dan sebagainya. Kelima kemampuan dasar ini harus mulai diajarkan dan dilatih sejak jenjang sekolah paling dasar (SD) yang akhirnya harus dimiliki dan dikuasai oleh peserta didik pada jenjang sekolah menengah sampai perguruan tinggi. Dengan mempelajari matematika banyak kemampuan berpikir yang terkait kognitif dilatih. Diantaranya berani memunculkan ide-ide penyelesaian masalah, nalar, kritis, kreatif, dan lain sebagainya. Bahkan, dengan belajar matematika mampu mengubah karakter seseorang (Rohana, 2015).

Latihan dengan bentuk soal-soal yang tidak berbeda dengan contoh, membuat peserta didik kurang tertantang dan terlatih untuk memancing munculnya ide-ide kreatif, serta mengasah penalaran mereka. Latihan soal sebaiknya dengan soal-soal bersifat non rutin dan tidak sama dengan contoh yang telah dibahas guru.

Hasil survei yang dilakukan pada penelitian pendahuluan di empat Madrasah Tsanawiyah Kota Bekasi, menemukan bahwa, soal-soal latihan matematika yang diberikan kepada peserta didik kelas 7 sebagian besar hampir sama seperti contoh yang sudah dijelaskan guru, atau contoh yang sudah dibahas pada buku paket. Perbedaannya terletak pada angkanya saja (pada saat studi pendahuluan, peserta didik MTs. sedang mempelajari materi persamaan dan pertidaksamaan linear satu variabel). Contoh latihan soal yang diberikan guru yang tidak berbeda dengan contoh yang sudah dijelaskan kepada peserta didik di dua madrasah yang berbeda, beserta jawaban peserta didik terlihat pada Gambar 1:

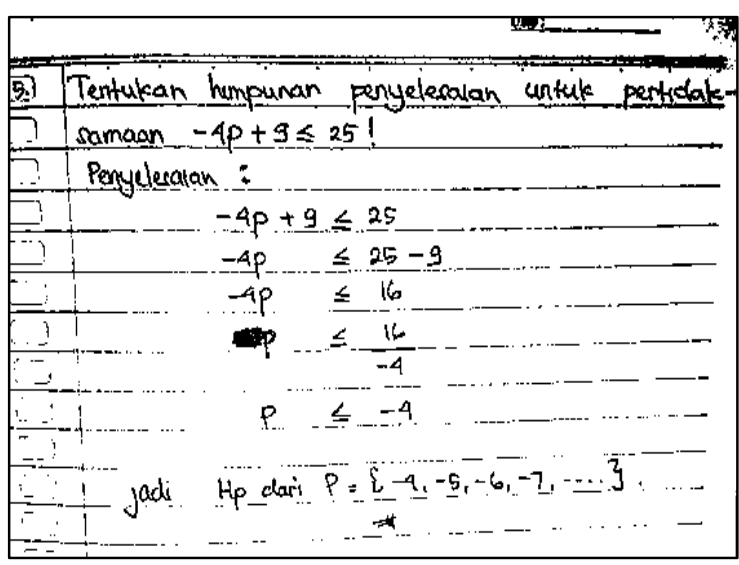

Jawaban peserta didik dari MTs. A

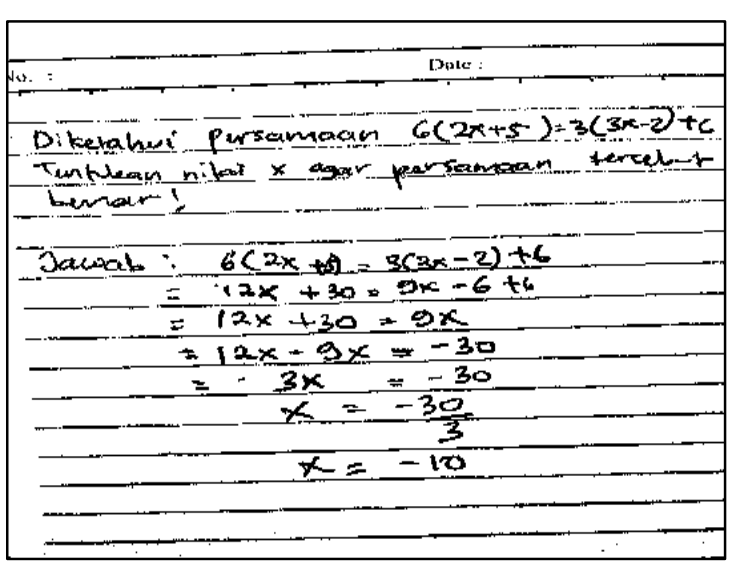

Jawaban peserta didik dari MTs. B

Gambar 1. Contoh Soal dan Jawaban Peserta Didik pada Studi Pendahuluan 
Jawaban peserta didik MTs. A, sekalipun soal latihan tidak berbeda dari contoh yang diberikan guru, namun siswa masih salah memahami konsep. Ketika mengalikan kedua ruas dengan $-\frac{1}{4}$, tanda $\leq$ tidak berubah menjadi $\geq$. Menuliskan urutan bilangan juga salah, padahal soal yang diberikan hanya membedakan angka dari contoh yang telah diberikan. Hasil pekerjaan peserta didik pada MTs. B sudah benar, walaupun masih ada konsep yang terlewat (pada langkah ke-enam, $3 x$ harusnya ditulis $\frac{3 x}{3}$ ).

Untuk menemukan masalah yang ada pada peserta didik di MTs. terkait pelajaran matematika, maka peneliti memberikan satu soal UN tahun lalu dan bersifat non-rutin kepada 116 peserta didik dari 4 MTs yang berbeda. Soal yang diberikan sebagai berikut:

Selisih panjang dan lebar sebuah persegipanjang adalah $6 \mathrm{~cm}$. Jika keliling persegipanjang tersebut $68 \mathrm{~cm}$, maka hitunglah luas persegipanjang tersebut!

Dari 116 peserta didik, hanya 10\% yang menjawab benar, dan $90 \%$ menjawab salah. Dari hasil wawancara dengan beberapa peserta didik menyatakan soal tersebut sulit dan tidak seperti contoh yang diberikan guru. Berdasarkan analisis hasil pekerjaan peserta didik, jenis kesalahan yang dilakukan disajikan pada Tabel 1:

Tabel 1. Data Jenis Kesalahan Jawaban Peserta Didik Pada Saat Studi Pendahuluan

\begin{tabular}{ccccc}
\hline \multirow{2}{*}{ Madrasah } & \multicolumn{4}{c}{ Kesalahan peserta didik, disebabkan: } \\
\cline { 2 - 5 } & $\begin{array}{c}\text { Tidak } \\
\text { paham } \\
\text { Konsep }\end{array}$ & $\begin{array}{c}\text { Tidak } \\
\text { punya ide }\end{array}$ & $\begin{array}{c}\text { Salah } \\
\text { menghi- } \\
\text { tung }\end{array}$ & $\begin{array}{c}\text { Tidak } \\
\text { menja- } \\
\text { wab }\end{array}$ \\
\hline A & 34,15 & 65,85 & 12,20 & 65,85 \\
B & 46,15 & 53,85 & 5,13 & 53,85 \\
C & 42,11 & 57,89 & 5,26 & 57,89 \\
D & 41,18 & 58,82 & 0 & 58,82 \\
\hline
\end{tabular}

Data pada Tabel 1, kesalahan terbanyak yang dilakukan peserta didik menyelesaikan soal UN yang bersifat non-rutin tersebut pada kriteria tidak punya ide (intuisi matematis), ditunjukkan dengan skor rerata sebesar 59,10\%. Karena ide mereka tidak muncul, berdampak tidak dapat menjawab soal tersebut. Diikuti tidak paham konsep, akibat peserta didik tidak nalar akan permasalahan yang diberikan. Selain tidak paham konsep, ada juga yang tidak benar dalam menghitung. Dari hasil wawancara, rendahnya kemampuan penalaran matematis disebabkan tidak memahami materi prasyarat. Dengan tidak memahami materi prasyarat maka tidak muncul ide untuk menyelesaikan masalah matematis. Berdasarkan data tersebut, dapat ditarik 
suatu kesimpulan bahwa intuisi dan penalaran matematis, merupakan dua kemampuan yang saling terkait dan mendukung dalam menyelesaikan masalah matematika.

Berdasarkan masalah yang ditemukan dilapangan, memperhatikan proses KBM, dan hasil wawancara pada empat madrasah (negeri dan swasta) saat studi pendahuluan, maka masalah yang akan diteliti: Apakah kemampuan berpikir intuisi dan penalaran matematis peserta didik secara keseluruhan dan berdasarkan kemampuan awal matematis yang diajarkan dengan pembelajaran Inquiry berbasis Open-ended lebih baik dari pembelajaran biasa? Dalam hal ini peneliti mencoba memberikan solusi agar meningkatkan munculnya ide atau intuisi dan penalaran matematis peserta didik di MTs. dengan mengaplikasikan pembelajaran inquiry berbasis Open-ended dan selanjutnya peneliti sebut dengan pembelajaran IBOE.

\section{Kemampuan Berpikir Intuisi Matematis}

Intuisi adalah sebuah kata yang hampir semua orang pernah mengatakannya, namun belum tentu memahami maknanya. Ada yang memaknai intuisi sebagai ide atau imajinasi, ada pula yang mengartikan dengan perasaan (feeling), insting, bahkan banyak yang asal mengucapkan kata intuisi tanpa tahu maknanya.

Pada awalnya, cukup sulit merumuskan pengertian kemampuan berpikir intuisi, khususnya kemampuan intuisi matematis yang akan dirujuk dalam penelitian ini. Penyebabnya adalah pandangan tentang kemampuan berpikir intuisi yang ditelusuri dalam literatur nampaknya dibangun dari acuan yang berbeda. Beberapa filsuf dan psikolog memberikan pandangan mengenai pengertian kemampuan berpikir intuisi didasarkan kepada perbedaan antara intuisi dengan aktifitas mental lainnya.

Zeev dan Star, (2002) menjelaskan pendapat Westcott yang menyatakan bahwa "The question of what exactly intuition is, in general, is relevant to a variety of domains, including philosophy, mathematics, psychology, and education”. Istilah intuisi dapat ditemukan pembahasannya pada masing-masing bidang kajian tersebut. Masing-masing bidang memberikan pandangan yang sesuai dengan perspektif bidang masing-masing. Dalam bidang filsafat, filsuf Bergson (1859-1941) membedakan antara intuisi dengan penalaran analitik. Menurutnya, kedua istilah tersebut tidak memiliki sistem kognitif yang berbeda, tetapi merupakan dua sisi dalam aktivitas berpikir. Dalam bidang psikologi, psikolog Jung (18751961) menyatakan bahwa intuisi adalah salah satu fungsi kognitif di antara tiga fungsi lainnya, yaitu: thinking, feeling, dan sensation (Henden G, 2004). Stanford Encyclopedia of Phylosophy mendefinisikan intuisi sebagai immediate apprehension atau pemahaman segera. Kata 
immediate atau segera tidak membutuhkan penyebab, kemampuan (ability), ataupun tidak memerlukan pembenaran (justifikasi). Sehingga dapat disimpulkan secara sederhana bahwa istilah intuisi merupakan ide atau "instinct" seseorang yang muncul secara tiba-tiba atau spontan untuk mengemukakan sesuatu yang ada dalam pikirannya dan tidak memerlukan pembenaran.

Hasil penelitian Usodo (2007) menyatakan bahwa, untuk memecahkan masalah matematika diperlukan proses berpikir analitis dan logis. Proses ini menunjukkan bahwa dalam menyelesaikan masalah matematika diperlukan suatu kegiatan kognisi formal. Akan tetapi kognisi formal tidak membantu peserta didik secara terperinci dalam setiap langkah menyelesaikan masalah matematika, terutama pada langkah awal. Oleh sebab itu, diduga ada aktivitas mental lain yang bukan kognisi formal dan membantu peserta didik menjadi kreatif dalam menyelesaikan masalah matematika yang dihadapi dan disebut kognisi intuitif (intuitive cognition) atau intuisi (Usodo, 2007).

Ivinson, et al. (2002) menyatakan bahwa, kemampuan berpikir intuisi adalah suatu gagasan intuitif. Secara umum, gagasan intuitif atau kemampuan intuisi adalah gagasan yang sangat berguna untuk menjelaskan cara memahami, mengamati, dan berpikir secara spontan dan alami tanpa banyak refleksi sadar yang disengaja, dan tidak memerlukan definisi dan pembenaran.

Zeev \& Star (2002) mempertegas pernyataan Westcott dengan menyatakan bahwa, konklusi yang berbasis kepada intuisi, secara khas dikarakterisasikan oleh informasi eksplisit yang sedikit/kurang dibanding informasi yang umumnya dibutuhkan untuk meraih konklusi tersebut. Para pemikir intuitif yang sukses, cenderung memiliki kecerdasan matematika yang tinggi dibanding lainnya (Zeev \& Star, 2002).

Fischbein (1987) mendefinisikan kognisi intuitif sebagai kognisi yang dikarakterisasikan oleh: self-evidence and intrinsiccertainty, perseverance and coeciveness, theory status and extrapolativeness, globality and implicitness. Fischbein menggunakan istilah intuisi ekivalen dengan pengetahuan intuitif yaitu: Intuisi bukan sebagai sumber (not as a source), bukan sebagai metode (not as a method), tetapi sebagai tipe kognisi.

Babai, et al. (2006) menjelaskan pendapat Fischbein, yang menyatakan bahwa kemampuan berpikir intuisi memiliki pengaruh besar pada respon peserta didik pada cara berpikir dalam sains dan matematika. Semua pernyataan yang merupakan intuisi diterima secara langsung tanpa perlu bukti secara formal maupun empiris. 
Ada 2 jenis intuisi, yaitu intuisi klasik dan intuisi inferensial. Pandangan intuisi klasik berguna untuk mengkaji intuisi primer. Pandangan intuisionis inferensial berguna untuk mengkaji intuisi sekunder (Zeev, 2002:7). Dari kedua pandangan terhadap intuisi (pandangan intuisionis klasik dan pandangan intuisionis inferensial) ditemukan dua perbedaan, bagaimana intuisi terkait dengan pengetahuan seseorang. Menurut pandangan intuisionis klasik, intuisi dibangun dari pengetahuan informal sehari-hari, misalnya intuisi anak prasekolah dalam melakukan perhitungan aritmetika sederhana seperti menghitung dan menjumlah. Pada sisi lain, dalam pandangan intuisionis inferensial, intuisi dibangun sebagai hasil dari pembelajaran atau pelatihan formal. Fischbein (1993) menyebut jenis intuisi yang pertama, intuisi primer dan jenis intuisi kedua, intuisi sekunder.

Penelitian ini difokuskan kepada intuisi peserta didik sekolah Madrasah Tsanawiyah (MTs) yang sedang mempelajari materi segiempat dan segitiga. Intuisi yang sesuai dengan pandangan peneliti untuk peserta didik kelas 7 yang masih pada tahap transisi dari berpikir konkrit ke berpikir abstrak (Piaget) pada materi geometri ini adalah pandangan intuisionis inferensial, yaitu intuisi matematika dibangun sebagai hasil pengalaman belajar peserta didik dari jenjang sebelumnya (intuisi sekunder). Karena materi segiempat dan segitiga sudah dipelajari peserta didik kelas 7 dari Sekolah Dasar.

Hirza (2014) dalam penelitiannya, mengembangkan tes intuisi dengan angket yang diadopsi dari tes intuisi Goldberg (tes your intuition). Instrumen intuisi pada penelitian Hirza berupa angket terdiri dari 32 butir pernyataan yang harus ditanggapi oleh siswa SD. Ke-32 butir pernyataan tersebut, setelah dianalisis mengukur indikator-indikator intuisi meliputi: (1) berlangsung seketika, (2) menggunakan sintesis, (3) benar dengan sendirinya, dan (4) global.

Berdasarkan teori yang telah dipaparkan dan hasil penelitian sebelumnya, maka indikator kemampuan berpikir intuisi matematis (selanjutnya disebut KBI) yang akan diteliti dari peserta didik MTs di Kota Bekasi diadopsi dari Fischbein (1993, 1987), Goldberg (1983), dan Zeev \& Star (2002) yaitu: (1) pengetahuan yang bersifat global (globality), (2) jelas dengan sendirinya serta tidak membutuhkan justifikasi atau pembuktian matematika (self evidence), (3) berdasarkan penarikan kesimpulan (synthesis), (4) berlangsung seketika (immediate). Penelitian ini masih mengukur indikator intuisi matematis yang hampir sama dengan peneliti sebelumnya (Hirza, 2014; Usodo, 2012), namun berbeda pada instrumen yang digunakan untuk mengumpulkan data. Peneliti sebelumnya menggunakan angket tes your intuition dari Goldberg, sedangkan penelitian ini menggunakan tes berbentuk uraian sebanyak 5 butir soal. Alasan pemilihan soal uraian adalah: ide yang dimunculkan pada langkah-langkah jawaban

Prima, Vol. 2, No. 2,Juli 2018, 107 - 126. 
peserta didik lebih terlihat jelas, baik berupa gambar maupun narasi. Sehingga ide-ide yang muncul lebih spesifik dan memberi gambaran yang jelas tentang intuisi matematis peserta didik.

\section{Kemampuan Penalaran Matematis}

Kata dasar dari penalaran adalah "nalar". Kamus Besar Bahasa Indonesia atau lebih dikenal dengan istilah KBBI (Depdiknas, 2008) mendefinisikan bahwa, nalar merupakan pertimbangan tentang baik dan buruk; aktifitas yang memungkinkan seseorang berpikir logis.

Menurut Kurikulum Matematika Sekolah, penalaran merupakan kemampuan dasar matematika yang harus dikuasai oleh peserta didik sekolah menengah (Permana \& Sumarmo, 2007). Penalaran merupakan proses pemikiran manusia yang berusaha tiba pada pernyataan baru yang merupakan kelanjutan runtut dari pernyataan lain yang diketahui. Pernyataan yang diketahui itu sering disebut dengan pangkal pikir (premis), sedangkan pernyataan baru yang ditemukan disebut kesimpulan.

Menurut Shurter dan Pierce yang dijelaskan oleh Purnamasari (2014), istilah penalaran diterjemahkan dari kata reasoning yang didefinisikan sebagai proses pencapaian kesimpulan logis berdasarkan fakta dan sumber yang relevan. Hal yang sama dinyatakan oleh Ball, Lewis \& Thamel yang dipaparkan dalam Riyanto (2011): "Mathematical reasoning is the foundation for the construction of mathematical knowledge”. Oleh sebab itu guru matematika pada jenjang sekolah dasar dan menengah harus mengembangkan kemampuan penalaran peserta didik dengan berbagai upaya, karena merupakan pondasi untuk memahami materi matematika.

Istilah penalaran matematis dalam beberapa literatur disebut dengan mathematical reasoning. Secara umum penalaran dibagi dalam dua jenis penalaran, yaitu penalaran induktif dan penalaran deduktif (Sumarmo, 2014: 456). Selanjutnya menurut Sumarmo (2014) penalaran induktif adalah penarikan kesimpulan umum berdasarkan pengamatan terhadap data terbatas. Akibat pengamatan yang terbatas, maka kebenaran penarikan kesimpulan tidak mutlak tetapi bersifat probabilistik. Penalaran induktif melibatkan keteraturan, sebagai contoh: menemukan jawaban dengan langkah coba-coba (trial and error) pada saat menentukan peluang munculnya angka pada dadu.

Permana \& Sumarmo (2007) menyatakan: Persamaan antara induksi dan deduksi adalah keduanya merupakan argumen yang mempunyai struktur, terdiri dari beberapa premis dan satu kesimpulan atau konklusi. Sedangkan perbedaannya, pada dasar penarikan kesimpulan dan sifat kesimpulan yang diturunkannya. Penarikan kesimpulan yang berdasarkan sejumlah kasus 
atau contoh terbatas disebut induksi, sedangkan berdasarkan aturan yang disepakati disebut deduksi.

Kemampuan penalaran dapat dikembangkan dengan proses pembelajaran matematika. Hal ini sesuai pendapat Soedjadi (2000), matematika merupakan ilmu pengetahuan yang diperoleh melalui bernalar. Sejalan dengan pendapat tersebut, Ruseffendi (2006) menyatakan bahwa, "matematika timbul karena pikiran-pikiran yang berhubungan dengan ide, proses, dan penalaran". Makna kedua pernyataan ini adalah usaha untuk memahami pengetahuan matematika diperlukan penalaran. Kemampuan penalaran matematis membantu peserta didik dalam menyimpulkan dan membuktikan suatu ide, pernyataan, membangun gagasan baru, sampai pada menyelesaikan masalah-masalah dalam matematika. Oleh karena itu, kemampuan penalaran matematis harus selalu dibiasakan dan dikembangkan dalam pembelajaran matematika. Hal ini sesuai dengan pernyataan Purwaningrum (2016: 102) yang menyatakan: "melalui pembelajaran matematika, siswa diberi kesempatan untuk mengembangkan kemampuan berpikir logis, kritis, kreatif, analisis, dan produktif".

Pendapat Soedjadi dan Ruseffendi sejalan dengan pendapat Plato yang dipaparkan oleh Dahlan (2011), apabila seseorang baik dalam matematika akan cenderung baik dalam berpikir, dan orang yang dilatih dengan belajar matematika akan menjadi pemikir yang baik. Oleh sebab itu, wajarlah jika kemampuan penalaran dapat dikembangkan melalui pembelajaran matematika. Wahyudin, dkk. (2010) dengan tegas menyatakan: Apabila peserta didik kurang menggunakan nalar dalam menyelesaikan masalah, maka akan gagal menguasai matematika dengan baik.

Penalaran matematis juga dapat dikembangkan melalui pengkonstruksian argumen,dengan cara mengajukan masalah dan meminta peserta didik menyelidiki apakah masalah itu sesuai dengan konsep yang dipelajari. Guru juga harus membiasakan peserta didik dalam menjawab soal harus disertai dengan alasan yang logis. Kebiasaan ini akan melatih peserta didik mampu menyampaikan argumen-argumen yang valid. Menguatkan pendapat tersebut, Turmudi (2009: 28) mengemukakan bahwa, kemampuan penalaran matematis adalah kemampuan mengungkapkan argumen yang sangat esensial untuk memahami matematika.

Selanjutnya Baroody (1993), mengungkapkan empat alasan mengapa penalaran penting untuk memahami matematika dalam kehidupan sehari-hari, khususnya pada saat mempelajari matematika. Ke-empat alasan tersebut adalah:

\section{The reasoning needed to do mathematics.}

Prima, Vol. 2, No. 2,Juli 2018, 107 - 126. 
2. The need for reasoning in school mathematics.

3. Reasoning involved in other content area.

4. Reasoning needed for everyday life.

Penalaran selain sebagai proses pengambilan kesimpulan, sangat dibutuhkan dalam memahami konsep matematika dan menyelesaikan masalah sehari-hari. Dengan pembelajaran matematika siswa diharapkan dapat menggunakan matematika sebagai cara bernalar (Sari, dkk., 2017). Menurut Jones, et al. (1999), penalaran matematis sebagai aktifitas dinamis yang melibatkan suatu variasi cara berpikir dalam memahami ide, merumuskan ide dan menemukan hubungan dan konklusi antara ide-ide tersebut.

Kemampuan penalaran matematis merupakan suatu kebiasaan atau habit dari pekerjaan otak yang harus dikembangkan secara konsisten dan kontinu dengan menggunakan berbagai macam konteks. Semakin dilatih, maka kemampuan penalaran akan semakin meningkat terutama dengan menyelesaikan soal-soal matematika yang non rutin dan Open-ended.

Berdasarkan pendapat pakar yang dirujuk, penalaran dan ide-ide matematis (intuisi matematis) saling mendukung dalam menyelesaikan masalah. Oleh sebab itu, kemampuan penalaran (selanjutnya disebut KPM) yang akan diteliti pada penelitian ini, disesuaikan dengan kemampuan berpikir peserta didik kelas 7 dan materi yang dipelajari, meliputi: (1) Memberikan penjelasan tentang suatu masalah dengan menggunakan konsep-konsep matematika terkait. (2) Memperkirakan jawaban dan proses solusi. (3) Menggunakan pola dan hubungan untuk menganalisis situasi matematik dan menggeneralisasi. (4) Menarik analogi dari permasalahan serupa. (5) Membuat keputusan dan menguji kebenaran jawaban. Kelima kemampuan ini disesuaikan dengan kemampuan penalaran peserta didik kelas 7 yang dijadikan subjek dalam penelitian ini.

\section{Pembelajaran Inquiry Berbasis Open-ended (IBOE)}

Pembelajaran IBOE dimodifikasi dari langkah-langkah pendekatan pembelajaran Inkuiri dan Open-ended. Berdasarkan langkah-langkah kedua pembelajaran tersebut, maka kedua pendekatan pembelajaran dapat dikolaborasi menjadi langkah-langkah model pembelajaran Inkuiri berbasis Open-ended (IBOE). Perpaduan tersebut diperoleh dari kesamaan sintaks pada kedua pendekatan pembelajaran. Dari kesamaan-kesamaan pada dua pembelajaran, disusun suatu langkah pendekatan pembelajaran IBOE yang merupakan pengembangan model pembelajaran yang diaplikasikan pada penelitian ini. 
Memadukan dua metode pembelajaran bukanlah hal baru dalam dunia penelitian. Sudah banyak peneliti sebelumnya yang menggunakan perpaduan dua metode bahkan lebih. Diantaranya Pratiwi, dkk., (2012) yang telah melakukan penelitian dengan mengaplikasikan Inkuiri terbimbing berbantuan My Own Dictionary untuk meningkatkan penguasaan konsep pelajaran fisika. Peneliti lainnya, Kartini (2011) yang menggunakan Inkuiri model Alberta untuk meningkatkan kemampuan berpikir kritis dan kreatif serta belief matematis. Memperhatikan peneliti-peneliti sebelumnya yang memadukan pembelajaran Inkuiri, menginspirasi peneliti untuk melakukan dan menerapkan pembelajaran Inkuiri berbasis Openended (IBOE). Pembelajaran IBOE yang diaplikasikan pada penelitian ini berbentuk belajar kelompok.

Proses memadukan kedua pendekatan pembelajaran tersebut merupakan aktifitas yang dilakukan melalui analisis. Peneliti menganalisis kesamaan yang ada pada kedua pembelajaran, khususnya langkah-langkah pembelajaran yang dapat meningkatkan kemampuan intuisi dan penalaran matematis. Setelah dianalisis disusun kembali, sehingga menjadi langkah-langkah pembelajaran IBOE pada Gambar 2:

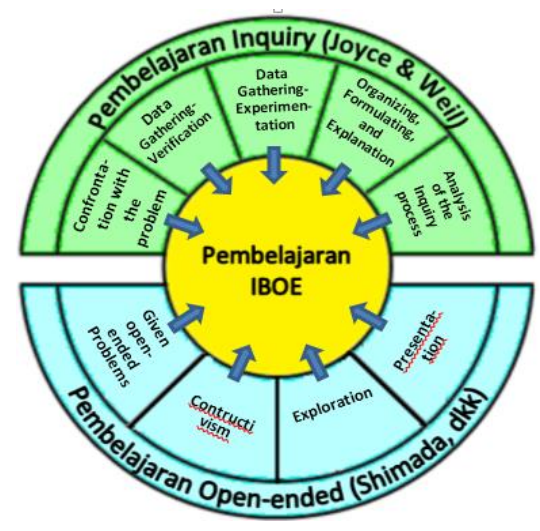

Gambar 2. Proses Modifikasi Pembelajaran Inquiry Berbasis Open-ended (IBOE)

Lima langkah pada pembelajaran Inkuiri (Joyce \& Well), dan empat langkah pada pembelajaran Open-ended (Shimada, et al.), setelah digabungkan mempunyai kesamaan yang dapat melebur menjadi satu langkah. Adapun langkah (sintaks) pembelajaran Inkuiri berbasis Open-ended (selanjutnya disebut IBOE) yang merupakan modifikasi dari pembelajaran Inkuiri dan pendekatan Open-ended yang diaplikasikan pada saat KBM sebagai berikut:

1. Guru secara langsung memberikan soal/masalah yang bersifat Open-ended yang dituangkan dalam bahan ajar dan LKS.

2. Pengumpulan data melalui verifikasi dengan bantuan bimbingan guru.

3. Pengumpulan data melalui eksperimentasi (coba-coba) menggunakan media yang disediakan guru.

Prima, Vol. 2, No. 2,Juli 2018, 107 - 126. 
4. Analisis proses menemukan. Pada langkah 3 dan 4, guru sebagai konsultan dan fasilitator.

5. Guru membimbing peserta didik dalam menganalisis untuk menemukan konsep dan penyelesaian jawaban.

Lima sintaks pembelajaran IBOE telah disesuaikan dan dituangkan dalam RPP K-13 di SMP/MTs. Selain itu penggabungan langkah yang hampir sama dipandang lebih efisien dan efektif pada saat diaplikasikan pada KBM matematika. Peneliti menduga dengan menerapkan langkah-langkah pembelajaran IBOE tersebut dapat meningkatkan kemampuan berpikir intuisi dan penalaran matematis peserta didik MTs.

\section{Pembelajaran Biasa}

Kelas kontrol pada penelitian ini menggunakan model pembelajaran biasa yang umum digunakan guru matematika di madrasah. Pembelajaran biasa yang dimaksud adalah pembelajaran yang memenuhi standar kurikulum yang berlaku saat ini. Ada dua kurikulum yang masih digunakan oleh dua madrasah di kota Bekasi, KTSP dan K-13. Praktik pembelajaran dalam konteks kedua kurikulum tersebut harus mengimplementasikan pembelajaran berbasis aktifitas dengan tujuan membentuk kualitas peserta didik (Abidin, 2014: 23). Kualitas yang dimaksud adalah kualitas memfasilitasi peserta didik mendapat pengetahuan dengan maksimal melalui segala upaya, dan meningkatkan ranah afektif menjadi manusia yang berakhlak mulia.

Pembelajaran biasa adalah strategi pembelajaran yang menekankan kepada proses penyampaian materi secara verbal dari seorang guru kepada sekelompok peserta didik, dengan tujuan peserta didik dapat menguasai materi secara optimal (Sanjaya, 2013: 179). Kelebihan pembelajaran biasa mudah mengaplikasikannya, tidak memerlukan persiapan yang khusus dan peserta didik mudah mengikutinya karena sudah familiar dengan pembelajaran biasa. Sehingga tidak banyak kendala yang dihadapi saat guru menggunakannya. Kekurangannya adalah aktifitas pembelajaran masih mayoritas berpusat pada guru.

Selanjutnya Sanjaya (2013: 185) mengidentifikasi beberapa langkah dalam penerapan model pembelajaran biasa yang dilakukan guru, meliputi: (1) Persiapan, (2) Penyajian, (3) Menghubungkan, (4) Menyimpulkan, dan (5) Penerapan/aplikasi.

Tahapan persiapan artinya peserta didik sudah disiapkan menerima materi pelajaran yang akan disampaikan oleh guru. Contoh tahap persiapan menyebutkan tujuan, menceritakan dengan singkat manfaat mempelajari materi matematika yang akan dipelajari, dan lain sebagainya. 
Tahap penyajian artinya guru menyajikan materi sesuai dengan persiapan yang telah dibuat, diawali dengan ceramah. Tahap menghubungkan artinya guru mampu mengaitkan materi yang akan dipelajari dengan pengetahuan yang telah dimiliki peserta didik, dilanjutkan dengan tanya-jawab, diskusi, dan penugasan. Tahap terakhir adalah menyimpulkan, artinya tahapan untuk memahami inti dari materi yang disampaikan. Mengaplikasikan artinya peserta didik mampu menunjukkan penerapan dari materi yang diberikan dalam menyelesaikan soal matematika terkait masalah-masalah pada kehidupan sehari-hari.

Kelemahan model pembelajaran biasa, hanya dapat dilakukan terhadap peserta didik yang memiliki kemampuan mendengarkan dan menyimak dengan baik (Sanjaya, 2013: 191). Tidak hanya itu, guru juga kurang dapat melayani perbedaan setiap individu secara merata. Pembelajaran biasa dengan tahapan tersebut tidak menarik untuk materi yang sifatnya pengulangan dari jenjang sebelumnya, karena akan terasa membosankan. Namun, tidak berarti model pembelajaran ini tidak memiliki kelebihan.

Pada kondisi tertentu model pembelajaran biasa dibutuhkan, terutama saat guru memberikan informasi atau materi ajar yang belum diketahui (belum pernah diterima) peserta didik pada jenjang sebelumnya. Dengan model pembelajaran biasa, materi pelajaran yang disampaikan dengan sistematis lebih mengaktifkan guru, sehingga memudahkan peserta didik untuk memahami materi yang diajarkan. Kelebihan lainnya, model pembelajaran ini dapat digunakan untuk jumlah peserta didik yang lebih banyak dan ukuran kelas yang besar. Untuk mengajarkan materi yang baru, dimana peserta didik belum pernah mempelajarinya pada jenjang sebelumnya, lebih efektif jika diajarkan dengan model pembelajaran biasa.

Berdasarkan paparan pakar yang dikutip sebelumnya, pembelajaran biasa yang diaplikasikan pada kelas kontrol, mempunyai prinsip pembelajaran sebagai berikut:

1. Hasil pembelajaran dan kriteria keberhasilan dibuat jelas bagi peserta didik.

2. Guru mengontrol waktu untuk berbagai aktifitas instruksional.

3. Guru mengatur dan mengendalikan urutan aktifitaspelajaran.

4. Ada penekanan pada prestasi akademik.

5. Guru dengan hati-hati memantau aktifitas dan pembelajaran peserta didik.

6. Guru memberikan umpan balik yang jelas kepada peserta didik 


\section{METODE PENELITIAN}

Penelitian ini merupakan penelitian quasi-experimental dengan rancangan penelitian yang digunakan adalah Nonequivalent Pre-test and Post-test Control-Group Design (Creswell, 2010; Sugiyono, 2009). Apabila digambarkan rancangan eksperimen tersebut sebagai berikut:

\begin{tabular}{lll}
$\mathrm{O}$ & $\mathrm{X}$ & $\mathrm{O}$ \\
\hline $\mathrm{O}$ & $\mathrm{O}$
\end{tabular}

Keterangan:

$\mathrm{X}$ : Pembelajaran dengan model IBOE.

$\mathrm{O}$ : Pretes atau postes Kemampuan Berpikir Intuisi dan Kemampuan Penalaran Matematis.

Peneliti memberikan perlakuan kepada subjek yang diteliti, untuk selanjutnya ingin diketahui pengaruh perlakuan tersebut terhadap dua variabel terikat yang diteliti, yaitu: peningkatan Kemampuan Berpikir Intuisi (KBI) dan Kemampuan Penalaran Matematis (KPM). Perlakuan yang akan diaplikasikan adalah pembelajaran IBOE (PI) dan pembelajaran biasa (PB).

Subjek penelitian adalah peserta didik kelas 7 yang terdaftar dan aktif pada semester genap tahun pelajaran 2016/2017 pada Madrasah Tsanawiyah A dan B di Kota Bekasi.

Pada penelitian ini, peserta didik dikelompokkan berdasarkan Kemampuan Awal Matematis (KAM) tinggi, sedang, dan rendah. Perhitungan KAM menggunakan 1/2 SD, supaya pada setiap kelas terdapat kelompok tinggi, sedang, dan rendah, serta tergambar sebagai sebuah kurva normal (Arikunto, 2013: 299).

Perhitungan kriteria KAM ( $\left.1 \frac{1}{2} \mathrm{SD}\right)$, juga mengacu pada penilaian acuan norma (PAN). Posisi nilai peserta didik dilihat berdasarkan kelompoknya, sehingga diperoleh jumlah sampel (peserta didik) dari kelas 7.1, 7.2, 7.3, dan 7.5 yang dikelompokkan pada KAM tinggi, sedang, dan rendah sebagaimana yang disajikan pada Tabel 2:

Tabel 2. Jumlah Subjek Penelitian Berdasarkan KAM $(1 / 2 \mathrm{SD})$

\begin{tabular}{ccc|ccc}
\hline \multirow{2}{*}{ Klmpk. KAM } & \multicolumn{4}{c}{ Kelompok \& Pembelajaran } & Jumlah \\
\cline { 2 - 5 } & $\begin{array}{c}\text { IBOE } \\
\text { (MTs. A) }\end{array}$ & $\begin{array}{c}\text { IBOE } \\
\text { (MTs. B) }\end{array}$ & $\begin{array}{c}\text { Biasa } \\
\text { (MTs. A) }\end{array}$ & $\begin{array}{c}\text { Biasa } \\
\text { (MTs. B) }\end{array}$ & $\begin{array}{c}\text { didik } \\
\text { Tinggi }\end{array}$ \\
\hline 10 & 10 & 9 & 9 & 38 \\
Sedang & 18 & 18 & 17 & 20 & 73 \\
Rendah & 11 & 10 & 12 & 12 & 45 \\
\hline Jumlah Sampel & & $\mathbf{7 7}$ & & $\mathbf{7 9}$ & $\mathbf{1 5 6}$ \\
\hline
\end{tabular}

Uji homogen dilakukan untuk melihat kesetaraan KAM antar kelompok menggunakan uji Levene, diperoleh nilai Sig $=0,413$ lebih besar dari $\alpha=0,05$. Hal ini membuktikan bahwa 
data KAM homogen, artinya ke-4 kelas yang dijadikan sampel penelitian memiliki KAM yang setara sebelum diberi perlakuan. Selain uji homogen, diujikan juga dengan uji perbedaan antar KAM tinggi, sedang dan rendah. Diperoleh hasil tidak ada perbedaan antara kelas pembelajaran IBOE dan pembelajaran biasa ditinjau berdasarkan KAM.

\section{HASIL DAN PEMBAHASAN}

Data KBI dan KPM diperoleh dengan memberikan 5 soal uraian yang sudah diujikan validitas dan reliabililitasnya kepada sampel, baik pada kelompok PI maupun PB. Data yang diperoleh (pretes dan postes) kemudian dilakukan uji normalitas (uji Kolmogorov-Smirnov) dan uji homogenitas (uji Levene) sebagai uji persyaratan untuk menentukan uji hipotesis. Selanjutnya data dihitung nilai Gain Normal (N-Gain) yang merupakan selisih antara data pretes dan postes untuk variabel yang diukur (KBI dan KPM) berdasarkan KAM dan keseluruhan. Deskripsi data $N$-Gain (data peningkatan) KBI disajikan pada Tabel 3 berikut:

Tabel 3. Deskripsi Data Peningkatan KBI

\begin{tabular}{lccc}
\hline \multirow{2}{*}{ KAM } & Pembelajaran & $\boldsymbol{N}$-Gain \\
& & KBI & Sd \\
\hline \multirow{2}{*}{ Tinggi } & IBOE & 0,797 & 0,147 \\
\multirow{2}{*}{ Sedang } & Biasa & 0,634 & 0,149 \\
\multirow{3}{*}{ Rendah } & IBOE & 0,696 & 0,153 \\
& Biasa & 0,492 & 0,122 \\
\multirow{2}{*}{ Keseluruhan } & IBOE & 0,528 & 0,149 \\
& Biasa & 0,323 & 0,096 \\
& IBOE & 0,676 & 0,179 \\
& Biasa & 0,473 & 0,166 \\
\hline
\end{tabular}

Terlihat pada Tabel 3, peningkatan KBI pada kelompok PI lebih tinggi dibandingkan PB ditinjau berdasarkan KAM maupun secara keseluruhan. Selanjutnya data peningkatan KBI berdasarkan level KAM diuji dengan uji perbedaan (uji-t), disajikan pada Tabel 4:

Tabel 4. Uji Perbedaan Peningkatan KBI Berdasarkan level KAM

\begin{tabular}{lccc}
\hline \multicolumn{1}{c}{ KAM } & Pembelajaran & $\mathbf{t}$ & Sig. \\
\hline Tinggi & $\begin{array}{l}\text { IBOE } \\
\text { Biasa }\end{array}$ & 3,391 & 0,001 \\
Sedang & IBOE & 6,287 & 0,000 \\
Rendah & Biasa & & \\
Keseluruhan & IBOE & 5,590 & 0,000 \\
\hline
\end{tabular}


Berdasarkan Tabel 4, terlihat nilai t untuk level KAM (tinggi, sedang, dan rendah) seluruhnya lebih besar dari tabel, dan nilai Sig. berdasarkan KAM (tinggi, sedang, dan rendah) kurang dari 0,05. Hal ini berarti hipotesis penelitian diterima, atau dengan kata lain: "Peningkatan kemampuan berpikir intuisi matematis peserta didik MTs yang mendapat pembelajaran IBOE lebih baik dari pada yang mendapat pembelajaran biasa ditinjau berdasarkan level KAM (tinggi, sedang, dan rendah)".

Secara keseluruhan diperoleh nilai $t=7,356$ dengan derajat kebebasan $(\mathrm{df})=154$ dan Sig. (2-tailed $)=0,000$. Karena uji hipotesis merupakan uji satu pihak, maka nilai Sig. (2-tailed) harus dibagi dua menjadi $\frac{0,000}{2}=0,000$. Nilai Sig. $(2$-tailed $)=0,000<\alpha=0,05$, artinya $\mathrm{H}_{0}: \mu_{1} \leq$ $\mu_{2}$ ditolak, dan $\mathrm{H}_{1}: \mu_{1}>\mu_{2}$ diterima. Hal ini mengindikasikan bahwa hipotesis penelitian yang menyatakan "Peningkatan kemampuan berpikir intuisi matematis peserta didik MTs yang mendapat pembelajaran IBOE lebih baik dari pada yang mendapat pembelajaran biasa ditinjau secara keseluruhan", dapat diterima. Kategori peningkatan KBI siswa MTs yang diadopsi dari Meltzer (2002) disajikan sebagai berikut:

Tabel 5. Rekap Kategori Peningkatan KBI Matematis secara Keseluruhan dan Level KAM

\begin{tabular}{lccc}
\hline \multicolumn{1}{c}{ Pembelajaran } & Level KAM & $\begin{array}{c}\text { Peningkatan } \\
(\boldsymbol{N} \text {-Gain })\end{array}$ & Kategori \\
\hline \multirow{2}{*}{ IBOE } & Tinggi & 0,7970 & Tinggi \\
& Sedang & 0,6956 & Sedang \\
& Rendah & 0,5281 & Sedang \\
\cline { 2 - 4 } & Tinggi & 0,6339 & Sedang \\
Biasa & Sedang & 0,4924 & Sedang \\
& Rendah & 0,3225 & Sedang \\
\hline Keseluruhan PI & & 0,6762 & Sedang \\
Keseluruhan PB & & 0,4730 & Sedang \\
\hline
\end{tabular}

Adapun deskripsi data peningkatan KPM disajikan pada tabel berikut:

Tabel 6. Deskripsi Data Peningkatan KPM

\begin{tabular}{lccc}
\hline \multicolumn{1}{c}{ KAM } & Pembelajaran & $\begin{array}{c}\text { N-Gain } \\
\text { KPM }\end{array}$ & Sd \\
\hline \multirow{2}{*}{ Tinggi } & IBOE & 0,828 & 0,142 \\
& Biasa & 0,667 & 0,136 \\
Sedang & IBOE & 0,540 & 0,105 \\
& Biasa & 0,538 & 0,093 \\
Rendah & IBOE & 0,211 & 0,160 \\
\multirow{2}{*}{ Keseluruhan } & Biasa & 0,301 & 0,104 \\
\end{tabular}




\begin{tabular}{lll}
\hline Biasa & 0,495 & 0,175 \\
\hline
\end{tabular}

Berdasarkan data peningkatan KPM pada Tabel 6, terlihat hanya peningkatan KPM kelompok KAM tinggi dan secara keseluruhan lebih baik PI dibandingkan PB. Namun untuk lebih meyakinkan harus dilanjutkan dengan melakukan uji perbedaan.

Uji perbedaan peningkatan KPM secara keseluruhan dan berdasarkan level KAM disajikan pada tabel berikut:

Tabel 7. Uji Perbedaan Peningkatan KPM

\begin{tabular}{lcccc}
\hline \multicolumn{1}{c}{ KAM } & Pembelajaran & $\mathbf{t}$ & $\mathbf{t}$ & Sig. \\
\hline \multirow{2}{*}{ Tinggi } & IBOE & 3,543 & - & 0,001 \\
\multirow{2}{*}{ Sedang } & Biasa & & & \\
\multirow{2}{*}{ Rendah } & IBOE & 0,093 & - & 0,463 \\
\multirow{2}{*}{ Keseluruhan } & Biasa & & & \\
& IBOE & $-2,274$ & & 0,014 \\
& Biasa & & & \multirow{2}{*}{0,026} \\
\hline
\end{tabular}

Data pada Tabel 7, menunjukkan nilai t hitung untuk level KAM tinggi $>\mathrm{t}_{\text {tabel }}$, dan nilai Sig. $<0,05$, hal ini berarti hipotesis penelitian diterima atau "Peningkatan kemampuan penalaran matematis peserta didik MTs yang mendapat pembelajaran IBOE lebih baik dari pada yang mendapat pembelajaran biasa ditinjau berdasarkan level KAM tinggi”.

Nilai t hitung untuk KAM sedang $<\mathrm{t}_{\text {tabel }}$ dan nilai Sig. $>0,05$, hal ini berarti hipotesis penelitian ditolak atau "Peningkatan kemampuan penalaran matematis peserta didik MTs yang mendapat pembelajaran IBOE tidak lebih baik dibandingkan dengan yang mendapat pembelajaran biasa ditinjau berdasarkan level KAM sedang”.

Nilai t untuk KAM rendah sekalipun negatif berada pada daerah penerimaan, dan nilai Sig. < 0,05, hal ini berarti hipotesis penelitian diterima atau "Peningkatan kemampuan penalaran matematis peserta didik MTs yang mendapat pembelajaran IBOE lebih baik dibandingkan dengan yang mendapat pembelajaran biasa ditinjau berdasarkan level KAM rendah".

Data peningkatan secara keseluruhan untuk kelas pembelajaran biasa berdistribusi normal namun tidak homogen, maka uji perbedaan menggunakan uji-t'. Nilai t' untuk KPM secara keseluruhan $<t_{\text {tabel }}$ atau berada pada daerah penolakan, dan nilai Sig. $>0,05$, hal ini berarti hipotesis penelitian ditolak atau "Peningkatan kemampuan penalaran matematis peserta didik MTs yang mendapat pembelajaran IBOE tidak lebih baik dibandingkan dengan yang 
mendapat pembelajaran biasa ditinjau secara keseluruhan". Kategori peningkatan KPM siswa MTs yang diadopsi dari Meltzer (2002) disajikan sebagai berikut:

Tabel 8. Rekap Kategori Peningkatan KPM secara Keseluruhan dan Level KAM

\begin{tabular}{lccc}
\hline \multicolumn{1}{c}{ Pembelajaran } & Level KAM & $\begin{array}{c}\text { Peningkatan } \\
\left(\boldsymbol{N}_{\text {Gain }}\right)\end{array}$ & Kategori \\
\hline \multirow{3}{*}{ IBOE } & Tinggi & 0,8275 & Tinggi \\
& Sedang & 0,5397 & Sedang \\
& Rendah & 0,2110 & Rendah \\
\hline \multirow{3}{*}{ Biasa } & Tinggi & 0,6672 & Sedang \\
& Sedang & 0,5297 & Sedang \\
& Rendah & 0,3013 & Sedang \\
\hline Keseluruhan PI & & 0,5248 & Sedang \\
\hline Keseluruhan PB & & 0,4953 & Sedang \\
\hline
\end{tabular}

\section{SIMPULAN DAN SARAN}

\section{Simpulan}

Berdasarkan hasil penelitian yang telah dipaparkan sebelumnya, maka disimpulkan:

1. Berdasarkan KAM dan secara keseluruhan, peningkatan kemampuan berpikir intuisi matematis peserta didik MTs. Yang diajarkan dengan pembelajaran IBOE lebih baik dibandingkan dengan pembelajaran biasa.

2. Peningkatan kemampuan penalaran matematis lebih baik pada kelas pembelajaran IBOE hanya untuk KAM tinggi dan rendah saja, namun tidak lebih baik pada KAM sedang dan secara keseluruhan. Artinya pembelajaran IBOE tidak dapat meningkatkan kemampuan penalaran matematis peserta didik secara keseluruhan dan KAM sedang.

3. Secara umum, pembelajaran IBOE berpengaruh positif untuk meningkatkan kemampuan berpikir intuisi matematis (KBI) dan kemampuan penalaran matematis (KPM) pada siswa Madrasah Tsanawiyah di Kota Bekasi.

\section{Saran}

Pembelajaran Inquiry Berbasis Open-Ended (IBOE) merupakan salah satu alternatif bagi guru matematika untuk meningkatkan kemampuan berpikir intuisi dan penalaran matematis peserta didik. Berdasarkan temuan dan hasil penelitian disarankan untuk peneliti selanjutnya dapat mengantisipasi kendala pada kelompok KAM sedang yang pada saat KBM jumlahnya mayoritas dibandingkan KAM tinggi dan rendah. Mengelompokan KAM siswa atau sampel 
yang diteliti sebaiknya membuat instrumen sendiri. Kelemahan dari penelitian ini, data KAM menggunakan nilai rata-rata UTS dan UAS murni.

\section{DAFTAR PUSTAKA}

Abidin, Y. (2014). Desain Sistem Pembelajaran dalam Konteks Kurikulum 2013. Bandung: Refika Aditama.

Arikunto, S. (2013). Dasar-dasar Evaluasi Pendidikan Ed.2 Cet.2. Jakarta: Bumi Aksara.

Babai, R. Brecher, T. Stavy, R. \& Tirosh, D. (2006). Intuitive interference in probabilistic reasoning. International Journal of Science and Mathematics Education, 4, 627-639. Taiwan: Kluwer Academic Publishers.

Baroody, A.J. (1993). Problem Solving, Reasoning, and Communicating, K-8, Helping Children Think Mathematically. New York: Macmillan Publishing Company.

Ben-Zeev, T. \& Star, J. (2002). Intuitive Mathematics: Theoretical and educational $\begin{array}{lllll}\text { Implications, } & \text { on } \quad \text { September } & 10, & 2015 & \text { from }\end{array}$ http://isites.harvard.edu/fs/docs/icb.topic654912.files/intuition.pdf.

Dahlan, J.A. (2011). Analisis Kurikulum Matematika. Jakarta: UT.

Depdiknas. (2008). Kamus Besar Bahasa Indonesia Pusat Bahasa Edisi Keempat. Jakarta: Gramedia Pustaka Utama.

Fischbein, E. (1993). The interaction between the formal, the algorithmic and the intuitive components in a mathematical activity. In R. Biehler, R. W. Scholz, R. Straser, \& B. Winkelmann (Eds.), Didactics of Mathematics as a Scientific Discipline, 231-245. USA: Kluwer Academic Publishers. . (1987). Intuition in Science and Mathematics. Israel: School of Education Tel Aviv University.

Hirza, B., Yaya Sukjaya, K., Darhim. (2014). Improving intuition skill with RME. IndoMS Journal on Mathematics Education, 5 (1), 127-34. Bandung: IndoMS.

Henden, G. (2004). Intuition and its Role in Strategic Thinking. Sandvika: BI Norwegian School of Management.

Ivinson, Gabrielle \& Bruce, T. (2002). Understanding and teaching the intuitive mind: Student and teacher learner. British Journal of Educational Psychology,). 72, 614-627. England.

NCTM. (2000). Principles and Standards for School Mathematics. [Online]:

https://www.nctm.org/uploadedFiles/Standards_and_Positions/PSSM_ExecutiveSummary.pdf. [6 September 2017]. 
Permana, Y., \& Sumarmo, U. (2007). Mengembangkan kemampuan penalaran dan koneksi matematik siswa SMA melalui pembelajaran berbasis masalah. Educationist,1 (2), 116123. Bandung: UPI Press. ISSN: 1907-8838.

Pratiwi, L., Sarwi, \& Handayani, L. (2012). Efektivitas model pembelajaran eksperimen ekspositori terbimbing berbantuan my own dictionary untuk meningkatkan penguasaan konsep dan unjuk kerja siswa SMP RSBI. Unnes Science Education Journal (hlm. 8695). 1 (2). Semarang: UNNES Press. ISSN: 2252-6617.

Purnamasari, Y. (2014). Pengaruh model pembelajaran kooperatif tipe teams games tournament (TGT) terhadap kemandirian belajar dan peningkatan kemampuan penalaran dan koneksi matematik peserta didik SMPN 1 kota Tasikmalaya. Jurnal Pendidikan dan Keguruan UT, 1 (1), artikel 2. Jakarta: UT Press.

Purwaningrum, J.P. (2016). Pengembangan kemampuan berpikir kreatif matematis melalui discovery learning. Pasundan Journal of Mathematics Education. 6 (2), 102-114. ISSN: 2089-2055.

Riyanto, B. (2011). Meningkatkan kemampuan penalaran dan prestasi matematika dengan pendekatan konstruktivisme pada siswa sekolah menengah atas. E-Jurnal Pendidikan Matematika Unsri,5 (2), 111-127. Palembang: Unsri Press.

Rohana, (2015). Meningkatkan karakter mahasiswa calon guru melalui pembelajaran reflektif. Jurnal Pendidikan Matematika UNPAS “SYMMETRY”, 4 (1), 571-582. Bandung: UNPAS Press.

Ruseffendi. E.T. (2006). Pengantar Kepada Membantu Guru Mengembangkan Kompetensinya Dalam Pengajaran Matematika untuk Meningkatkan CBSA. Bandung: Tarsito.

Sanjaya, W., (2013). Strategi Pembelajaran Berorientasi Standar Proses Pendidikan Cetakan ke-10. Jakarta: Kencana Prenada Media Group.

Sari, I.P., Yenni, Aji R., (2017). Pengaruh pendekatan pembelajaran contextual teaching and learning (ctl) terhadap kemampuan penalaran matematis siswa SMP 1. Prima: Jurnal Pendidikan Matematika 1 (1), 19-32. Tangerang: UMT. P-ISSN: 2579-9827, E-ISSN: 2580-2216.

Soedjadi, R., (2000). Kiat Pendidikan Matematika di Indonesia. Jakarta: Dirjen Dikti Depdiknas.

Sumarmo, U., (2014). Kumpulan Makalah: Berpikir dan Disposisi Matematika serta Pembelajarannya. Bandung: FMIPA UPI. 
Turmudi, (2009). Landasan Filosofis dan Teoritis: Taktik dan Strategis Pembelajaran Matematika. Jakarta: Leuser Cita Pustaka.

Usodo, B., (2012). Karakteristik intuisi siswa SMA dalam memecahkan masalah matematika ditinjau dari kemampuan matematika dan perbedaan gender. AKSIOMA, 01 (01), Maret 2012. Surakarta: Universitas Sebelas Maret. (2007). Peran Intuisi dalam Pemecahan Masalah. Makalah disampaikan pada Konferensi Nasional Pendidikan Matematika (KNPM) II di UPI Bandung pada tanggal 25-27 Agustus 2007.

Wahyudin, Sutikno \& Isa, A., (2010). Keefektifan pembelajaran berbantuan multimedia menggunakan metode ekspositori terbimbing untuk meningkatkan minat dan pemahaman siswa. Jurnal Pendidikan Fisika Indonesia6, 58-62. ISSN: 1693-1246. 